\title{
Gaining Insights into Preparatory School Instructors' and Students' Metaphorical Images of EFL Writing Instructors through Metaphor Analysis
}

\author{
Kaya Nur ÇALIȘIR GÖVENÇ* \\ Istanbul Bilgi University, İstanbul, Turkey
}

Yeşim KEŞLİ DOLLAR

Bahcesehir University, İstanbul, Turkey

Article history

Received:

27.10.2016

Received in revised form: 15.12.2016

Accepted:

17.12.2016

Key words:

Writing, Instructors, English as a Foreign Language (EFL), Preparatory School Students, Metaphor, Perception, Teacher Cognition.
The purpose of this study is to investigate the English Preparatory School instructors' and students' metaphorical images of English as a Foreign Language (EFL) writing instructors at a foundation university in Istanbul, and also, explore whether there is any consistency of the conception of metaphorical images of EFL writing instructors given by preparatory school students and preparatory school English instructors. A sample of 58 EFL instructors and 335 students participated in this study. Data was obtained through metaphor surveys and semi-structured interviews. The findings of the study showed that most of the instructors and students have a tendency to generate metaphors in the Learner-Centered Growth perspective. It is also suggested that preparatory school instructors' and students' metaphorical images and cognitions of EFL writing instructors should be surfaced and acknowledged. Therefore, EFL writing instructors should look into their teaching ways and styles to detect good or other parts to consider in their teaching styles under the light of tacit and unexamined thoughts coming from both students and instructors. Lastly, EFL instructors and teacher educators and trainers may have an idea how they are perceived, how they teach and how students learn.

\section{Introduction}

The fields of L2 writing and teachers cognition have become one of the essential research topics in recent years. There have been some studies on these areas separately (Borg, 1999; Borg, 2003; Hammerness, 2003; Seferoğlu, 2009; Korkmazgil, \& Ölçü, 2009), but it seems difficult to find an exact and appropriate research if it is needed to combine them in a qualified study. Teachers' attitudes and beliefs have a great impact in the classroom environment, the relations to their students and their own learning process (Borg, 2003; Richardson, 1996).

Writing is a complex process, which requires written production of EFL learners. It can be observed that EFL learners have difficulties in writing compositions in another language. In order to be successful, they sometimes trust on their beliefs and what they have brought into

\footnotetext{
*Correspondence:nur.govenc@bilgi.edu.tr
} 
the class and felt about the writing course and their writing instructors. As good writing instructors, it is necessary to find out students' beliefs and attitudes towards writing and EFL writing instructors via something appropriate and useful such as metaphors. The use of metaphor in education, especially in terms of getting idea of instructors' and students' beliefs and previous experiences which have been brought with them to the classroom environment, is seen as a productive tool by Munby and Russel (1989). Thornbury (1991) focuses on the importance of uses of metaphor that consist of teachers' beliefs and values. Therefore, this study may provide an opportunity for EFL writing instructors, students, researchers, and teacher trainers to be aware of their cognitions, attitudes and beliefs towards EFL writing instructors, students and writing lessons. Additionally, with the light of this study and similar studies (Cabaroglu \& Roberts, 2000; Norman \& Spencer, 2005; Peacock, 2001) changing beliefs and attitudes in a different longitudinal study through metaphor conceptualization can be examined.

During the last two decades, there has been a gradual emergence of a different conception of teaching as a process of active decision-making informed by teachers' cognitions- the beliefs, knowledge, assumptions, theories, and attitudes about all aspects of their work teachers have. However, the topic of this study has been ever-growing body of research in a range of diverse instructional settings, in pre-service and in-service contexts, at various levels, and with respect to a wide range of subjects such as English and Science (Borg, 1999). Teacher cognition can be defined as "what teachers think, know and believe and the relationships of these mental constructs to what teachers do in the language classroom" (Borg 2003, p. 81). According to educational researchers, understanding teachers' ways of thinking about teaching, learning and other school-related issues mean having an idea about their influence on their classroom practices and their own professional growth (Seferoğlu, Korkmazgil, \& Ölçü, 2009).

Lee (2010) states that while much more attention has been paid to the needs of students who are learning how to write in EFL context, EFL writing teachers should also be taken into consideration to understand their needs, decisions, attitudes and beliefs towards students in and out of class. Villamil and Guerrero (2005) state that EFL teacher educators focus on the process by which student teachers form and develop ideas about the teaching of L2 writing which can get difficult in the first year of teaching experience. It is implied that it is not too late to consider in-service EFL writing teachers to scaffold them when they feel unqualified or insufficient.

Metaphor, which makes a lot of studies more creative and makes teachers' or students' feelings, beliefs and attitudes touchable, has been an important concept in the EFL world in recent years (Baş \& Bal-Gezegin, 2015). There are a lot of researchers who give various definitions of the term "metaphor". For instance, Lakoff and Johnson (1980a) state that metaphors are overarching, mostly shared understandings that support discourse and social cognition, so organize people's existence. It is typically viewed as the characteristic of language alone, a matter of words rather than thought or actions. Moreover, Berliner (1990) claims that "metaphors are powerful forces, conditioning the way we come to think of ourselves and others.... They affect our thoughts in subtle but powerful ways" (p.2). While Perry and Cooper (2001) support this idea, they believe that metaphors help us shape what we say and how we form our thoughts about concepts via metaphors. Therefore, metaphor seems to be the best way to gather concrete data on teachers' or students' beliefs and attitudes on educational studies. 
There have been plenty of researchers who used metaphors in gaining insight about preservice or in-service teachers' ways of thinking, making decisions and their beliefs in various levels, contexts, and subjects (Aktekin, 2013; Belcher \& Yiğitoğlu, 2014; Berliner, 1990; Chris \& Cooper, 2001; Farrell, 2006; Furuoko \& Nikitina, 2008; Goldstein, 2005; Hunby \& Russell, 1989; Lakoff \& Johnson, 1980a; Lakoff \& Johnson, 1980b; Leavy et al., 2007; McEwan, 2007; Nunan, 1998; Pinnegar et all, 2010; Seferoğlu et all; 2009; Stofflett, 1996; Thornbury, 1991; Thomas \& Beauchamp, 2011; Villamir \& Guerrero, 2005; Yesilbursa, 2012). In the light of these studies conducted so far and with the support of metaphorical images of instructors and students, this study has an objective to find out the English preparatory school instructors' and students' metaphorical images of EFL writing teachers, and then to focus on the consistency between two various data.

Like in many countries where English is spoken as a foreign language, students first have to successfully pass in English at preparatory schools to fulfill the conditions of their department requirements To achieve their goals, they try to deal with their insufficient motivation, plenty of rules, which show the right ways of writing English compositions, and follow their writing instructors who make their students' intrinsic motivation increase with the aid of their presence and materials in class. They lack motivation in terms of communication or creative production in writing. According to Casanave (2009), EFL writing instructors have to constantly deal with the question on how to integrate best activities in teaching context. When the focus has been on teacher for years, the problem is that EFL writing instructors shouldn't be underestimated. How are they seen by themselves and their students? How are they described?

As some of the problems EFL writing instructors faces in or out of class have been mentioned above, there are lots of studies dealing with various issues in writing, metaphors, or instructor education (Fenwick, 2000; Pinnegar et al., 2011; Seferoglu et. al., 2009; Stofflett, 1996; Thomas \& Beauchamp, 2011; Villamil \& Guerrero, 2005; Yeşilbursa, 2012; Yigitoglu \& Belcher, 2014). However, it is difficult to find research studies on the metaphorical images of EFL writing instructors in the literature. To fill this gap, the consistency between metaphorical images of EFL writing instructors from the eyes of both sides -students and instructors- was examined in this study. In other words, this study aims to investigate the English preparatory school instructors' and students' metaphorical images of writing instructors, and explore whether there is any consistency between their metaphorical images on their mind.

The purpose of this study is to seek answers to the following questions:

(1) What are the English preparatory school instructors' metaphorical images of EFL writing instructors?

(2) What are the English preparatory school students' metaphorical images of EFL writing instructors?

(3) What is the consistency of the conception of metaphorical images of EFL writing instructors given by preparatory school students and preparatory school English instructors? 


\section{Methodology}

\section{Research Design}

Mixed methods research approach was used in this study. In this research, the goal is to find out the metaphorical images of preparatory school students and instructors and the consistency of the conception of metaphorical images. Therefore, the data collected through a survey, which made the study qualitative and analyzed through content, frequency, and chisquare analysis, which made the study quantitative. To use both research method approaches in this study can provide a better understanding and solutions to the researchers and the research problems. Additionally, the data of this study was collected at one point in time to explore the metaphorical images of preparatory school students and instructors. Thereby, it can be known as cross-sectional study to show the attitudes and beliefs at a specific time.

\section{Setting}

The study was conducted at the English Preparatory School at a foundation (nonprofit) university in Istanbul, Turkey. Before students start to study at their departments, they have to get sufficient score to pass an Oxford placement test online in the beginning of the year. The academic year in English preparatory school is comprised of a total of 5 modules which include 8 weeks per module. The levels are separated into modules like Breakthrough (A1- Elementary), Waystage (A2- Pre-Intermediate), Threshold (B1- Intermediate), Vantage (B2- Upper-Intermediate), and optional EAP (C1- Advanced) in regard to CEF (Common European Framework). When students are placed to an appropriate module considering their test results, they receive 20 hours of English instruction per week in each level. The program includes two basic courses, main course (16 hours) and reading-writing which, mainly focus on developing students' writing skills. The writing lessons have two parts: in and out of class writing. The first written product is written by the students when the related reading part and exercises are finished in class, and then in the second phase, instructor checks and gives feedback to the students to correct their mistakes.

\section{Participants}

For this study, data was gathered from 43 Turkish EFL instructors, 15 native English instructors and 335 Turkish students. The native instructors were from different countries, which were not taken into consideration in the study. The instructors' demographic data in the first part of the instructors' and students' surveys show the distribution of 58 instructors and 335 students. Since the effects of the instructors' and students' nationalities were not the focus of the study, it was not taken into the consideration. Additionally, some of $\mathrm{MA}$ and $\mathrm{PhD}$ degrees were on progress, which was not taken into the consideration in this study (see Table 1 and 2).

Table 1. The results of instructors' demographic data

\begin{tabular}{llll}
\hline \multicolumn{1}{c}{ Categories } & & $\mathrm{F}$ & $\%$ \\
\hline \multirow{3}{*}{ Age } & $25-30$ & 36 & $62 \%$ \\
& $31-35$ & 10 & $17 \%$ \\
\multirow{3}{*}{ Gender } & 36 and more & 12 & $21 \%$ \\
& Female & 37 & $64 \%$ \\
Nationality & Male & 21 & $36 \%$ \\
& Other & 15 & $26 \%$ \\
Educational Background & Turkish & 43 & $74 \%$ \\
& BA & 22 & $38 \%$ \\
& MA & 32 & $55 \%$
\end{tabular}




\begin{tabular}{llll} 
& PhD & 4 & $7 \%$ \\
& $0-1$ year & 2 & $3 \%$ \\
Teaching Experience & 2-5 years & 34 & $59 \%$ \\
& 6-10 years & 10 & $17 \%$ \\
Total & 11 years and more & 12 & $21 \%$ \\
\hline
\end{tabular}

Table 2. The results of students' demographic data

\begin{tabular}{llll}
\hline Categories & & F & $\%$ \\
\hline \multirow{2}{*}{ Gender } & Male & 165 & $49 \%$ \\
& Female & 170 & $51 \%$ \\
Age & $18-20$ & 221 & $66 \%$ \\
& $20-25$ & 110 & $33 \%$ \\
Level of English & $30-\ldots$ & 4 & $1 \%$ \\
& A1-A2 & 70 & $21 \%$ \\
Nationality & B1-B2 & 260 & $78 \%$ \\
Total & C1-C2 & 5 & $1 \%$ \\
& Turkish & 332 & $99 \%$ \\
& Other & 3 & $1 \%$ \\
& & 335 & $100 \%$ \\
\hline
\end{tabular}

\section{Data collection instruments}

\section{University Preparatory School Students' and Instructors' Metaphor Survey}

University preparatory school students' and instructors' metaphor surveys included the demographic data of the EFL students, EFL native and non-native instructors in the first part. In the second part of the survey, they were asked to complete a sentence using metaphor. That part of the survey, a sentence completion part "A writing teacher is like..." was prepared in the frame of similar studies (Guerrero \& Villamil, 2001; Nikitina \& Furuoka, 2008; Seferoglu, 2009; Villamil \& Guerrero, 2005) to find out what they think of EFL writing teachers and how they describe them.

\section{University Preparatory School Students' and Instructors' Semi-Structured Interview}

In order to get more detailed information from the participant students' and instructors' about their metaphorical images of EFL writing instructors and writing lessons, the semi-structured interviews were carried out separately. Interview questions were constructed in accordance with the survey. Semi-structured interviews included 7 open-ended questions. These questions were about the feelings of the participant students' and instructors' towards English writing lessons, the description of writing lessons using a metaphor, and the best and the worst part of a writing lesson during a class hour. Additionally, the questions asked if they liked their writing teacher, how they could describe a writing teacher or themselves as a writing teacher, what the role of writing teacher is, and their expectation from a writing instructor and a writing lesson. Finally, they answered the question- what kind of writing teacher helps them enjoy and learn writing lessons more than they felt and learnt at that moment.

\section{Data Collection Procedures}

The data was gathered through a foundation university in Istanbul. The participant students' data was gathered with the help of other instructors. The researcher gave the survey to as many classes as possible to reach different levels of students to have more 
heterogeneous group for the study. In addition to this, the researcher chose some of the students who could express their thoughts and feelings clearly from the target group students for semi-structured interview. The next step was to gather data from the instructors. While 58 instructors and 335 students were asked to fill in the University Preparatory School Instructors' Metaphor Survey, 8 volunteer instructors and 28 volunteer students took semistructured interview. .

\section{Data Analysis}

The data gathered for this study were analyzed both qualitatively and quantitatively. For all the research questions of the study, the data was obtained from the participant students' and instructors' surveys and semi-structured interviews (see Table 3). In the first part of the surveys, the demographic data were analyzed by hand with an instructor for inter rater reliability because of the limited number of items that were asked. Then, the answers of the sentence completion in the second parts which included metaphor were analyzed by the frequency showing the number of the words given by the participants. The researcher and a colleague identified metaphors given by the participants and put them under the predefined themes in the frame of four philosophical perspectives. In this study, Oxford et al.'s four perspectives on education (1998) were used to analyze the data including metaphors. According to Oxford et al.'s perspectives (1998), these metaphors can be clustered into four different philosophical perspectives: Social Order, Cultural Transmission, Learner-Centered Growth and Social Reform.

The Social Order Perspective is the most common image of schooling. It aims the well-being of the society and students are perceived as resources to meet social needs. The teacher is seen as a technician who is molding learners for the needs of society. The second philosophical perspective is the Cultural Transmission, which is mostly associated with elicit vision of high culture and intellectual education. It supports curricula that relate individual development as a process of enculturation. Whereas there are different views on this perspective, which are called as classicists and multiculturalists, a teacher is seen as a gatekeeper who leads students into a good life made by culturally and has a good understanding of cultural values and expressions. In contrast to the previous perspectives, the Learner-Centered Growth perspective supports the idea, which learners have natural talent in education. Additionally, it is stated that learners can bring out all the inborn powers and capacities. Instead of forcing students to carry out what their teachers wants, this perspective gives a chance to students to discover themselves and flourish their minds, which makes teacher like a gardener to create a positive learning environment. The last perspective, Social Reform, is difficult to understand in terms stressing elements from other three movements. It has a shred teacher-and-student control. It also focuses on encouraging multiple viewpoints in community of learners.

The next stage of the procedure was to analyze the data from the semi-structured interviews with both the students and the instructors. The data was analyzed through the content analysis. Content analysis (Miles \& Huberman, 1994; Weber, 1990) was started by categorizing them from the codes for each set of data which was related to a specific question. All the categories and themes taken from the content analysis were double-checked by a colleague to have a significant degree of inter-rater reliability.

For the answer of the last research question, Chi-Square Test was used to reveal whether there is any consistency of the conception of metaphorical images of writing instructors given by 
preparatory school students and preparatory school English instructors. Chi-Square Test is a statistical test, which is preferred for categorical data (Howell, 2014). In this research, ChiSquare test was analyzed on SPSS (Statistical Package for the Social Sciences).

Content analysis was also used in the semi-structured interviews in this study. Therefore, data collected from the participants were analyzed in the light of this information about content analysis.

Table 3. The overview of the research questions and corresponding procedures

\begin{tabular}{|c|c|c|}
\hline Research Questions & Data Collection Instruments & Data Analysis \\
\hline $\begin{array}{l}\text { 1. What are the English preparatory } \\
\text { school instructors' metaphorical images } \\
\text { of EFL writing instructors? }\end{array}$ & $\begin{array}{l}\text { University Preparatory School Instructors' } \\
\text { Metaphor Survey, Semi-structured } \\
\text { Interviews carried out with instructors }\end{array}$ & $\begin{array}{l}\text { Frequency Analysis, Content } \\
\text { Analysis (Miles and } \\
\text { Huberman, 1994; Weber, } \\
\text { 1990) }\end{array}$ \\
\hline $\begin{array}{l}\text { 2.What are the English preparatory } \\
\text { school students' metaphorical images of } \\
\text { EFL writing instructors? }\end{array}$ & $\begin{array}{l}\text { University Preparatory School Instructors' } \\
\text { Metaphor Survey, Semi-structured } \\
\text { Interviews carried out with students }\end{array}$ & $\begin{array}{l}\text { Frequency Analysis, Content } \\
\text { Analysis (Miles and } \\
\text { Huberman, 1994; Weber, } \\
\text { 1990) }\end{array}$ \\
\hline $\begin{array}{l}\text { 3. What is the consistency of the } \\
\text { conception of metaphorical images of } \\
\text { EFL writing instructors given by the } \\
\text { preparatory school students and } \\
\text { instructors? }\end{array}$ & $\begin{array}{l}\text { University Preparatory School Instructors' } \\
\text { Metaphor Survey, Semi-structured } \\
\text { Interviews carried out with students }\end{array}$ & $\begin{array}{l}\text { Chi- Square Test (Howell, } \\
\text { 2014) }\end{array}$ \\
\hline
\end{tabular}

\section{Results}

\section{University Preparatory Instructors' Metaphor Survey Results}

The analysis of the metaphors showed how EFL writing instructors were perceived by themselves via a conceptual metaphor. The overall distribution of the instructors' metaphors on the four perspectives is shown in the Table 4 below.

Table 4. The overall distribution of the instructors' metaphors on the four perspectives

\begin{tabular}{|c|c|c|c|c|}
\hline $\begin{array}{l}\text { Four Perspectives of } \\
\text { Oxford et al. }\end{array}$ & Typology 1 & Typology 2 & $\mathrm{~F}$ & $\%$ \\
\hline \multirow{5}{*}{ 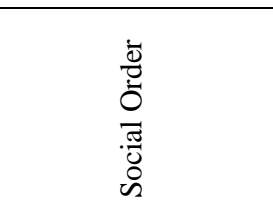 } & \multicolumn{2}{|l|}{ Teacher as Manufacturer } & 8 & $14 \%$ \\
\hline & \multicolumn{2}{|l|}{ Teacher as Competitor } & 0 & $0 \%$ \\
\hline & \multicolumn{2}{|l|}{ Teacher as Hanging Judge } & 0 & $0 \%$ \\
\hline & \multicolumn{2}{|l|}{ Teacher as Doctor } & 4 & $7 \%$ \\
\hline & \multicolumn{2}{|l|}{ Teacher as Mind and Behavior } & 4 & $7 \%$ \\
\hline \multirow{2}{*}{ 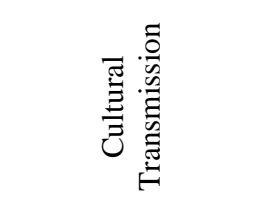 } & \multirow{2}{*}{\multicolumn{2}{|c|}{$\begin{array}{l}\text { Teacher as Conduit } \\
\text { Teacher as Repeater }\end{array}$}} & 15 & $26 \%$ \\
\hline & & & 0 & $0 \%$ \\
\hline \multirow{7}{*}{ 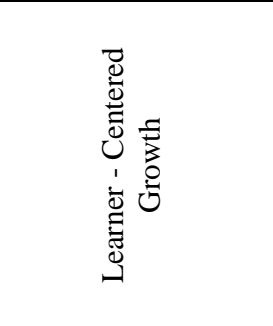 } & \multirow{4}{*}{ Teacher as Nurturer } & Caretaker & 5 & $9 \%$ \\
\hline & & Animals & 3 & $5 \%$ \\
\hline & & Food & 1 & $2 \%$ \\
\hline & & N. Elements and Resources & 5 & $9 \%$ \\
\hline & \multirow{2}{*}{\multicolumn{2}{|c|}{$\begin{array}{l}\text { Teacher as Lover or Spouse } \\
\text { Teacher as Scaffolder }\end{array}$}} & 0 & $0 \%$ \\
\hline & & & 5 & $9 \%$ \\
\hline & Teacher as Entertainer & Positive & 6 & $10 \%$ \\
\hline
\end{tabular}




\begin{tabular}{|c|c|c|c|}
\hline & Negative & 2 & $3 \%$ \\
\hline & Teacher as Delegator & 0 & $0 \%$ \\
\hline 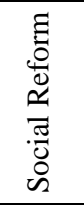 & $\begin{array}{l}\text { Teacher as Acceptor } \\
\text { Teacher as Learning Partner }\end{array}$ & 0 & $\begin{array}{l}0 \% \\
0 \%\end{array}$ \\
\hline Total & & 58 & $100 \%$ \\
\hline
\end{tabular}

First of all, the Social Order perspective, which constituted $28 \%$ of the total sampling as outlined by Oxford et al. (1998), has a big control over learning and teaching processes. It shapes learners through external reinforcement (Oxford et al., 1998). The examples from the instructors' metaphors that fit in this perspective are head of state, engineer, architect, and traffic police. Among the metaphors given under this perspective, there were also Typologies like teacher as manufacturer, teacher as competitor, teacher as hanging judge, teacher as doctor, and teacher as mind-and-behavior. In this perspective only teacher as manufacturer, teacher as doctor and teacher as mind-and-behavior were found through the metaphors given by the instructors. While teacher as manufacturer (14\%) were described as worker, engineer, or architect to show how to build teaching on students' learning, teacher as doctor typology $(4 \%)$ is the teacher as detective or detector in terms of showing what is true and false. The last metaphor the study included is teacher as mind-and-behavior controller (7\%) is a teacher which is kind of traffic police or leader. They try to control what students think and do and lead students to have them obey the rules of learning.

A traffic police. S/he directs the drivers (students) to drive their vehicles (words) in an orderly fashion. (Instructor 9, March 16, 2015)

An engineer. We show our students how to use the base material of language to design a meaning structure. (Instructor 10, March 16, 2015)

The second perspective of education as outlined by Oxford et al. (1998) is the Cultural Transmission (26\%) with 15 metaphors in total. In this approach, the teacher is a "unidirectional information-giver" (p.7). While all these metaphor examples below are in relation to the Teacher as Conduit metaphor in Oxford et al.'s (1998) typology; metaphors in Teacher as repeater typology were not observed.

A navigator who explains the route but does not give a lift or take you to your destination. (Instructor 11, March 16, 2015)

A road map. She shows you the best possible way to reach your destination. (Instructor 13, March 16, 2015)

As the third perspective, the Learner-Centered Growth perspective of education as outlined by Oxford et al. (1998) constituted $47 \%$ of the total sampling. The researcher added some categories to make analysis clearer and easier such as teacher as caretaker, food, animals and teacher as natural elements and resources, which are groups to a similar study (Nikitina \& Furuoka, 2008). Teacher as caretaker (5\%) has a character that teaches and cares for children. The metaphors given by the instructors are mother and gardener. These are the examples taken from the instructors' metaphors:

The mother of a toddler. She or he does everything to help her child to stand up and start to walk, but all she can do is to support. The only one who can perform the desired activity is the toddler itself. (Instructor 15, March 16, 2015)

A gardener. She or he first prepares the ground and then step by step does the planting, watering, nourishing, et as much as she can do so that she or he might reap the harvest in the end. (Instructor 16, March 16, 2015)

Secondly, animals and food categories had 4 metaphors such as octopus, butterfly, and onion 
in total. Additionally, teacher as natural elements and resources (9\%) was the last typology the instructors gave, and its number was significant in terms of the study results. The examples are like tree, star, butterfly and cloud.

These perceptions above correspond to Oxford et al.'s (1998) Teacher as Nurturer which is under the Learner-Centered Growth perspective of education as outlined by Oxford et al. (1998). It is the largest group in this framework. Oxford et al. (1998) state that LearnerCentered Growth perspective shares the control over learning between the teachers and students, which shows the balance in teaching and learning. The other typology under this perspective below is teacher as scaffolder (9\%) including coach (3) and guide (2) metaphors. Guerro and Villamil (2001) had a similar category named as cooperative leader that included similar metaphors such as coach and guide. Guerro and Villamil (2001) stated that coach metaphor showed the need for "constant encouragement, support, feedback, and opportunities for practice and using the L2" and the need for "interaction between teacher and learners and among learners (p.10). Teacher as entertainer (13\%) which was divided into two categories, negative and positive, included metaphors such as playing the violin, chess, and idling car which were taken from the instructors' metaphor examples. Lastly, the Social Reform perspective of education as outlined by Oxford et al. (1998) was not found among the metaphor generated by the participant instructors in this study $(0 \%)$. This perspective was developed by Dewey (1993 as cited in Oxford et al., 1998). To have more democratic society is the aim of this approach, and the class can be an example of "democratic community" (Oxford et al., 1998, p. 41)

\section{University Preparatory Instructors'Semi-Structured Interview Results}

The questions of the semi-structured interview with 8 university preparatory school instructors about their metaphorical images of EFL writing instructor were analyzed with the help of content analysis. The answers of the first, third and fourth questions were combined and explained together since they required similar types of answers from the instructors related to their attitudes and beliefs towards writing, writing instructors, and writing lessons. The first question aimed to find out whether the instructors like English writing lessons or not, and the results of their answers showed that 6 out of 8 instructors gave yes answer. The aspects that they liked were seeing their students' efforts on their papers, their students' motivation to write, the ability to produce the language, and satisfaction of teaching. However, 2 instructors had negative answers because of the lack of writing background of the students and the difficulties that they have in a writing lesson. The third question also asked the instructors what the best and the worst parts of teaching a writing lesson are. It can be inferred from almost all the instructors' answers that the best part of teaching in a writing lesson had a relation with the production, and the worst part included some kinds of problems such as structure, ability, unappealing topics, and time limits. Additionally, the fourth question required the answers of the instructors on their beliefs and attitudes towards their writing teaching styles. Four of the instructors stated that they did not like their teaching styles, or they were not sure about their teaching styles in a writing lesson. While some of the instructors liked good rapport with their students and feeling competent about writing lessons, others stated a few problems such as time management, limitations and the pacing in a writing lesson.

The second and fifth questions asked the instructors how they could describe a writing lesson and a writing teacher in one word, and what made them think like that. For the second question, 3 of the instructors gave three words which have negative meanings such as 
uncontrolled, pain, and agony. The difficulty of understanding and producing a proper written paper came at the beginning of their problems. The rest of the instructors had positive attitudes toward a writing lesson and they described a writing lesson as creativity, cooking, production, cooperation, and puzzle, which showed their points of views. For the fifth question, most of the instructors stated their problems about enthusiasm of their students about writing, a big need to have not only a wide range of vocabulary but also be really good at grammar, and keeping an eye on all the students and make them work collectively.

Lastly, the sixth and seventh questions of the semi-structured interview asked the instructors what the role of a writing teacher in a writing lesson, what they expect to teach a student, and what kind of writing teacher helps students enjoy and learn writing lessons more than the students feel and learn. With regard to the answers of the instructors for the question six, they described the role of a writing teacher as a guide, a purpose to make students more autonomous, the leading force, a leadiator, and a facilitator. They also expected to teach a student writing lesson by giving clues, leading them to find their own ways and think creatively, encouraging them, and accepting the diversity of the students. For the last question, the instructors tried to describe the ideal type of a writing teacher who helps students enjoy and learn writing lessons more than they feel and learn with some points such as an understanding, patient and creative writing teacher who includes audio visual materials, collaborative activities and games in the class. Therefore, the instructors believe that their student will learn in a better way.

\section{University Preparatory Students' Metaphor Survey Results}

In the analysis of students' metaphor survey, all similar metaphors were grouped under the same category in the frame of Oxford et al.'s four perspectives on education (1998). Additionally, almost all the metaphors were grouped under the typologies in the light of similar studies (Aktekin, 2013; Belcher \& Yiğitoğlu, 2014; Berliner, 1990; Chris \& Cooper, 2001; Farrell, 2006; Furuoko \& Nikitina, 2008; Goldstein, 2005; Hunby \& Russell, 1989; Lakoff \& Johnson, 1980a; Lakoff \& Johnson, 1980b; Leavy et al., 2007; McEwan, 2007; Nunan, 1998; Pinnegar et all, 2010; Seferoğlu et all; 2009; Stofflett, 1996; Thornbury, 1991; Thomas \& Beauchamp, 2011; Villamir \& Guerrero, 2005; Yesilbursa, 2012). The overall distribution of the metaphors collected from the participant students was seen in the Table 5 . In the frame of Oxford et al.' typology (1998), the metaphors were put under the right categories. To make groups clearer and easier, the researcher added Typology 2 part in the framework, which was similar to Nikitina and Furuoka's (2008) study. Total number of metaphors gathered from the students was $335(100 \%)$. It can be seen that the number of the metaphors fallen under the Social Order was $31(9 \%)$. The Cultural Transmission perspective had 83 metaphors, constituting $25 \%$ of the sampling group. The next perspective, The Learner Centered Growth, had the largest proportion in this study with the significant number, 194 metaphors (58\%). On the other hand, the Social Reform perspective was the smallest group with 27 metaphors, constituting $8 \%$ of the sampling group. The metaphors, which could not be categorized by the researcher because of ambiguity in the meaning, were not taken into consideration and were excluded from the research analysis and results.

Table 5. The overall distribution of the students' metaphors on four perspectives 


\begin{tabular}{|c|c|c|c|c|}
\hline $\begin{array}{c}\text { Four Perspectives of } \\
\text { Oxford et al. }\end{array}$ & Typology 1 & Typology 2 & $\mathrm{~F}$ & $\%$ \\
\hline \multirow{5}{*}{ 离 } & Teacher as Manufacturer & & 11 & $3 \%$ \\
\hline & Teacher as Competitor & & 1 & $0 \%$ \\
\hline & Teacher as Hanging Judge & & 4 & $1 \%$ \\
\hline & Teacher as Doctor & & 2 & $1 \%$ \\
\hline & Teacher as Mind and Behavior & & 14 & $4 \%$ \\
\hline \multirow{3}{*}{ 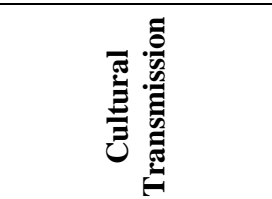 } & & & & \\
\hline & Teacher as Conduit & & 82 & $24 \%$ \\
\hline & Teacher as Repeater & & 1 & $0 \%$ \\
\hline \multirow{9}{*}{ 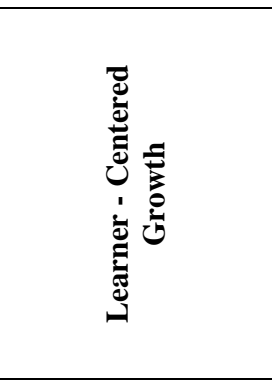 } & \multirow{4}{*}{ Teacher as Nurturer } & Caretaker & 17 & $5 \%$ \\
\hline & & Animals & 16 & $5 \%$ \\
\hline & & Food & 17 & $5 \%$ \\
\hline & & $\begin{array}{l}\text { Natural Elements and } \\
\text { Resources }\end{array}$ & 94 & $28 \%$ \\
\hline & Teacher as Lover or Spouse & & 0 & $0 \%$ \\
\hline & Teacher as Scaffolder & & 10 & $3 \%$ \\
\hline & \multirow{2}{*}{ Teacher as Entertainer } & Positive & 33 & $10 \%$ \\
\hline & & Negative & 7 & $2 \%$ \\
\hline & Teacher as Delegator & & 0 & $0 \%$ \\
\hline \multirow{2}{*}{ 氶 } & Teacher as Acceptor & & 1 & $0 \%$ \\
\hline & Teacher as Learning Partner & & 26 & $7 \%$ \\
\hline Total & & & 335 & $100 \%$ \\
\hline
\end{tabular}

Although each typology seems so similar to another, there are small differences between them. The Social Order perspective, which comes first in the framework, constituted 9\% of the total sampling. Teacher as manufacturer and Teacher as mind-and-behavior were the most two popular typologies chosen by the students. Whereas Teacher as manufacturer (4\%) were mostly based on jobs such as author, painter, and writer, Teacher as mind-and-behavior typology (4\%) had metaphors showing teacher's power in class such as leader, superman, queen of class, and king. The next typology under this perspective is Teacher as competitor having only $1(0 \%)$ metaphor, sprinter. This conceptual metaphor showed that teacher can compete with her/his students for control in classroom. Teacher as hanging judge and teacher as doctor were other typologies which were not popular with constituting 2\% (6 metaphors) among the students in this study. While boss, religion, and prophet metaphors showed capricious teacher type, dentist and doctor metaphors had meaning of finding students' mistakes, making them correct and giving remedies in the form of exercises. The most preferable metaphors by the students were writer (2) and author (2) in Teacher as manufacturer, boss (2) in Teacher as hanging judge, and leader (3) in Teacher as mind-andbehavior.

Another distribution of the metaphors gathered from the students can be categorized under the Cultural Transmission perspective. It constituted $25 \%$ of the total sampling with 83 metaphors. It has two types of typology in this perspective, Teacher as conduit and Teacher as repeater. Students had a tendency to give metaphors related to the Teacher as conduit typology with 82 metaphors, which was the largest number $(24 \%)$. The frequency of the metaphors generated by the students in Teacher as conduit typology showed that book, compass, dictionary, map, and encyclopedia, were the most preferable metaphors by the students. There was only one metaphor $(0 \%)$ in Teacher as repeater group: Robot (1). As seen in the metaphors given by the students, the Cultural Transmission perspective had typologies which showed the teacher is unidirectional information giver (Oxford et al., 1998). 
The third perspective is the Learner-Centered Growth, which had the largest group of metaphors gathered from the students. It constituted 58\% of the total sampling with 194 metaphors in total. The significant number of the conceptual metaphors can be seen under Teacher as nurturer typology (43\%) with 144 metaphors. Whereas Teacher as lover or spouse and Teacher as delegator had no metaphors (0\%) generated by the students, Teacher as scaffolder had 10 metaphors (3\%) such as teacher, coach and guide. The second largest group following Teacher as nurturer typology was Teacher as entertainer which formed $12 \%$ (40 metaphors) of the student sampling group.

In order to categorize clearly and easily, the researcher added four groups related to the content of the typology under Teacher as nurturer, which had the biggest proportion (43\%) in this study. The groups were called caretaker, animal, food, natural elements and resources, which all had meaning related to nurturer metaphor indeed. Whereas caretaker, animals, and food groups constituted only $15 \%$ of the sampling in total, teacher as natural elements and resources group was still bigger than the total proportion of the previous three groups itself. Caretaker group had 17 metaphors (5\%) with the most popular one, mother, and the next group, which was called as animals also constituted almost same number (5\%) of metaphors (16) with the most frequent one, lion.

The last significant typology is Teacher as entertainer which had the second largest group of metaphors gathered from the students in the Learner - Centered Growth perspective. It constituted $12 \%$ of the total sampling with 40 metaphors in total. The significant number of the conceptual metaphors can be seen under Teachers as nurturer typology (43\%) with 144 metaphors. Teacher as lover or spouse and Teacher as delegator had no metaphors (0\%) generated by the students. The second largest group following Teacher as nurturer typology was Teacher as entertainer which formed 12\% (40 metaphors) of the student sampling group.

Finally, the forth perspective of Oxford et al.'s perspectives (1998) is the Social Reform which constituted $8 \%$ of the total sampling with 27 metaphors given by the students. Whereas Teacher as acceptor typology had only one metaphor, psychologist, Teacher as learning partner had 26 metaphors with the most frequent one, friend.

\section{University Preparatory Students'Semi-Structured Interview Results}

The researcher conducted a semi-structured interview with 28 students who were chosen randomly. The questions of the semi-structured interview with university preparatory school students about their metaphorical images of EFL writing instructor were analyzed and put under the categories with the help of content analysis.

\section{Q1: Do you like English writing lessons? Why/ Why not?}

The semi-structured interview started with a general question related to the lesson and the justification from the students. 18 students (64\%) gave yes answer to this question, and 10 students (36\%) said no. As a reason to their yes and no answers, the researcher tried to make their answers as much as shorter, took phrases and put them under two categories as positive and negative reasons in the table. While enjoyable (3), important (3), good (2) and useful (2) were the most frequent answers in the positive part, boring (4) and dislike writing (2) answers were significant in the negative part.

Q2. How can you describe a writing lesson in one word? What makes you think like that? 
The students were required to provide one word to describe a writing lesson in their mind and they were supposed to justify their answers with the second question. The most frequent answers were educational (4), unnecessary (2) and boring (2). While 6 words given by the students had negative meaning, the rest of them were still positive. Their justification to their one word answers were in a harmony with the words they had given.

Q3. What is the best and worst part of participating in a writing lesson? Why/ Why not?

The students were supposed to state their attitudes towards participating in a writing lesson, and they needed to justify their answers. The answers were not categorized by the frequency in this question since the answers from each student were in the same line under the best and worst parts. One of the students did not give an answer for the worst part category. While most of the students focused on learning (sth.) in the best part, the answers of the second part included 3 negative words frequently such as boring, difficult and long.

\section{Q4. Do you like your writing teacher? Why/ Why not?}

The question wanted to learn how the students' attitudes towards their writing teacher and whether there was a relation between enjoying writing lesson and teacher. $100 \%$ of the student participants told they liked their teacher, and they had no problems. To support their answers, they used some frequent words and phrases such as helpful (4), helpful and kind (3), and good (3). Additionally, there were 3 students who did not give an answer for justification their yes. that?

Q5. How can you describe a writing teacher in one word? What makes you think like

In this question, the students tried to describe their attitudes and feelings towards a writing teacher in a word. Whereas the first part of the question included a word, the second part had words or phrases which the researcher got using content analysis to justify their answers. There were no common words to categorize, but except unwilling word which did not have an explanation in the second part. The answers focused on the positive sides of a writing teacher such as mother, book, and helpful.

Q6. What is the role of a writing teacher in a writing lesson? What do you expect to learn from a writing teacher?

The question asked the students to think deeply and give answers in relation to their dream writing teachers and lessons. While 28 students (100\%) provided answers for the first part of the question, 6 students did not state anything about their expectations in the second part. For the role of a writing teacher, the first part of the question had lots of similar phrases such as correcting mistakes, knowing everything and teaching writing. The second part of the question had a focus on learning new vocabulary.

Q7. What kind of writing teacher helps you enjoy and learn writing lessons more than you feel and learn now? Briefly explain.

The last question was similar to the previous one in regard to having an idea about a perfect writing teacher of the students. The most frequent answers gathered from the students were enjoyable (4) and funny (3) writing teacher. In addition to this, the students preferred a writing teacher who sings a song, plays games (2) and focuses on writing lessons (2). 


\section{The Consistency of the Metaphorical Conception between University Preparatory School Instructors' and Students' Results}

To be able to make this study more reliable, Chi-square test was used to find whether there was a consistency between the two participant groups and metaphors given by the two participant groups under the four perspectives of Oxford et al. (1998) for the last question of the study. Firstly, the researcher had the percentage and the frequency of the data gathered from the instructors and students, and it was analyzed by SPSS. The participant groups were called as occupation variable in the cross-tabulation table.

Table 6. Cross-tabulation of the variables

\begin{tabular}{|c|c|c|c|c|c|}
\hline \multirow{13}{*}{ 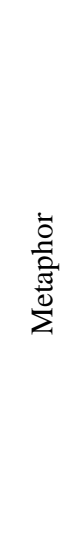 } & & & $\begin{array}{l}\text { Occupation } \\
\text { Instructor }\end{array}$ & Student & Total \\
\hline & \multirow[t]{3}{*}{ Social Order } & Count & 16 & 31 & 47 \\
\hline & & $\%$ within metaphor & $34 \%$ & $66 \%$ & $100 \%$ \\
\hline & & $\%$ within occupation & $27,6 \%$ & $9,3 \%$ & $12 \%$ \\
\hline & \multirow[t]{3}{*}{ Cultural Transmission } & Count & 15 & 83 & 98 \\
\hline & & $\%$ within metaphor & $15,3 \%$ & $84,7 \%$ & $100 \%$ \\
\hline & & $\%$ within occupation & $34,5 \%$ & $27,8 \%$ & $28,8 \%$ \\
\hline & \multirow[t]{3}{*}{ Learner Centered Growth } & Count & 27 & 194 & 221 \\
\hline & & $\%$ within metaphor & $12,2 \%$ & $87,8 \%$ & $100 \%$ \\
\hline & & $\%$ within occupation & $37,9 \%$ & $54 \%$ & $51,7 \%$ \\
\hline & \multirow[t]{3}{*}{ Social Reform } & Count & 0 & 27 & 26 \\
\hline & & $\%$ within metaphor & $0 \%$ & $100 \%$ & $100 \%$ \\
\hline & & $\%$ within occupation & $0 \%$ & $8,1 \%$ & $6,9 \%$ \\
\hline \multirow[t]{3}{*}{ Total } & & Count & 58 & 335 & 393 \\
\hline & & $\%$ within metaphor & $14,8 \%$ & $85,2 \%$ & $100 \%$ \\
\hline & & $\%$ within occupation & $100 \%$ & $100 \%$ & $100 \%$ \\
\hline
\end{tabular}

In chi-square test, the number of cells, which were expected to have lower value than 5 should not exceed the $20 \%$ of the total number cells. In this analysis, since the number of the cells who were expected to have lower value than 5 constituted $12,5 \%$ of the total cells, that kind of problem did not exist. When the table analyzed (see Table 6), the results were like that: While the $27,6 \%$ of the instructors gave metaphors in the Social Order perspective, $9,3 \%$ of the students were in the same perspective. Secondly, 34,5\% of the instructors and 27, $8 \%$ of the students had metaphors in the Cultural Transmission perspective. The Learner-Centered Growth perspective included $37,9 \%$ of the instructors and $54 \%$ of the students. Lastly, whereas the Social Reform perspective did not have any metaphors from the instructors, 8,1\% of the students created metaphors for this perspective. The top perspective chosen by both participant groups was the Learner-Centered Growth.

Table 7. Chi Square test results on the variables

\begin{tabular}{llll}
\hline Chi-Square Tests & & \\
\hline & Value & dh & Asymp. Sig. 2-sided \\
Pearson Chi-Square & 19,726 & 3 & 0 \\
Likelihood Ratio & 20,683 & 3 & 0 \\
N of Valid Cases & 393 & & \\
\hline
\end{tabular}

a. 1 cells $(12,5 \%)$ have expected count less than 5 .

The minimum expected count is 3,98 
Table 8. Symmetric Measures of Chi-Square Test

\begin{tabular}{llll}
\hline Symmetric Measures & & & \\
\hline & & & Approx. Sig. \\
Nominal by Nominal & Phi & 0,224 & 0,00 \\
& Cramer's V & 0,224 & 0,00 \\
& Contingency Coefficient & 0,219 & 0,00 \\
N of Valid Cases & & 393 & \\
\hline
\end{tabular}

The results of the analysis (see Tables 7 and 8) showed that there was a significant association between the two variables, two participant groups (instructors-students) and the four perspectives which included teachers' typologies (the Social Order, the Cultural Transmission, the Learner-Centered Growth, and the Social Reform): $\mathrm{X}^{2}(\mathrm{sd}=3, n=335)=$ 19,726 p $<.05$. Therefore, there was a significant and meaningful correlation between the participant groups and metaphors given by the two participant groups under the four perspectives of Oxford et al.'s (1998) study.

\section{Discussion of the Findings}

The study revealed that there were similar procedures done by the researchers to this study, which was mostly based on "teacher" conception (Farrell, 2006; Nikitina \& Furuoka, 2008; Pinnegar et al., 2011; Saban, 2007; Seferoglu, 2009; Stofflett, 1996; Thomas and Beauchamp, 2011; Yesilbursa, 2012). First, whereas the English preparatory school instructors' metaphorical images of EFL writing instructors were based on the LearnerCentered Growth and the Cultural Transmission perspectives at almost same rate, the students' metaphorical conceptions focused on the Learner-Centered Growth with the highest proportion among the other perspectives. To sum up, it means almost all preparatory school instructors and students conceptualize their EFL writing teachers as knowledge provider, nurturer, cultivator, and conduit, which is parallel to Saban et al.'s (2007) study and Seferoglu's (2009) study.

One of the biggest differences between groups was that the high number of the instructors' metaphors under the Social Order perspective. However, the students' metaphors under this perspective showed that they do not perceive their EFL writing instructors as an authority. Additionally, there was a big gap between the students and instructors' metaphors under the Social Reform perspective. This can be inferred that even if the instructors sometimes think they are like friends with their students, their tacit thoughts unearthed through metaphor analysis claim that they conceptualize themselves or writing instructors as knowledge provider, nurturer, cultivator, and conduit as students do. It can be because of the culture in which they live, which was mentioned in Nikitina \& Furuoka's study (2008). Instructors could look into their own and students' inner thoughts deeply, and have awareness of their teaching styles and expectations from their students as a writing instructor.

Additionally, the consistency between these two groups and the perspectives has not been analyzed in any study so far. The importance of this study is that the results reveal the consistency of tacit and unearthed thoughts of the most important stones, students and instructors, of education. Additionally, it shows that preparatory school students and instructors are on the same track in terms of the perceptions of EFL writing instructors and lessons. Both groups sometimes have difficulties, hard times in teaching and learning writing skill, but they never reject to teach or learn. Instead, they would like to teach and learn interesting, purposeful, and authentic topics with the guidance of their instructors or effort of the students in an interactive way in a positive atmosphere. This could be a reference to 
instructors who have difficulty in coping with their students to teach writing skill. Additionally, it could be used as a tool to find out their students' expectations and perceptions of a writing instructor and a writing class, so instructors may use metaphors as the most powerful source for change (Thornburry, 1991).

Lastly, the results provided significant implications for teacher education programs. This may suggest that teachers' cognitions in regard to EFL writing instructors and teaching writing should be taken into consideration, and "they should be seen as source to reach tacit or unexamined beliefs into objectively rational beliefs since these beliefs can affect their how they teach and how students learn." (Seferoglu, 2009, p.334). Regarding the results found through the metaphors analysis, teacher trainers can also provide in-service training programs, which can be online to make the programs available for all writing instructors. Additionally, metaphors created by students and instructors could be helpful for both participant groups since they are not just the reflections of unexamined thoughts and personal values, but also directly or indirectly influence the classroom performance of the writing instructors (Thornburry, 1991). To sum up, Guerro and Villamil (2001) recommended that "the use ofmetaphor as a tool to increase self-reflection among L2/FL teachers" can be used for writing teachers (p.11).

\section{Conclusion}

To conclude, in terms of teacher educators and trainers, this study fills a gap of EFL writing instructors' metaphorical images, which were provided by them and students who were exposed to a writing course at English preparatory school. When their beliefs and attitudes towards a writing instructor are embodied with their own words, teacher educators and trainers can detect EFL writing instructors' problems clearly, and provide appropriate solutions in order to turn the effects of writing instructors' beliefs and attitudes in class into positive and effective tools for their students. In terms of EFL writing instructors, it is also suggested that preparatory school instructors' and students' metaphorical conceptions and cognitions of EFL writing instructors should be surfaced and acknowledged, and that EFL writing instructors should look into their teaching ways and styles under the light of tacit and unexamined thoughts coming from both students and instructors to detect good or other part to consider again; so, with the help of metaphor analysis, EFL instructors may have an idea how they are perceived, how they teach and how students learn.

\section{References}

Aktekin, N. Ç. (2013). Revealing ESL Teachers' and Students' Attitudes and Beliefs through Metaphors. Retrieved March 3, 2015 from http://kutuphane.uludag.edu.tr/Univder/uufader.htm

Armstrong, D., Gosling, A., Weinman, J., \& Marteau, T. (1997). The place of inter-rater

Berliner, D. C. (1990). If the metaphor fits, why not wear it? The teacher as executive. Theory into practice, 29(2), 85-93.

Baş, M., \& Bal-Gezegin, B. (2015). Teachers as patience stones: A metaphor analysis of students'conceptualizations of EFL teachers in Turkey. Journal of Foreign Language Teaching and Applied Linguistics, 1(3).

Borg, S. (1999). Studying teacher cognition in second language grammar teaching. System, 27(1), 19-31.

Borg, S. (2003). Teacher cognition in language teaching: A review of research on what language teachers think, know, believe, and do. Language Teaching, 36(02), 81-109. 
Casanave, C. P. (2009). Training for writing or training for reality? Challenges facing EFL writing teachers and students in language teacher education programs. Writing in Foreign Language Contexts: Learning, Teaching, and Research, 256-277.

Creswell, J. W. (2013). Research design: Qualitative, quantitative, and mixed methods approaches. Sage publications.

Farrell, T. S. (2006). 'The Teacher Is an Octopus' Uncovering Pre-service English Language Teachers' Prior Beliefs through Metaphor Analysis. RELC Journal, 37(2), 236-248.

Fenwick, T. (2000). Adventure guides, outfitters, fire starters, and caregivers: Continuing educators' images of identity. Canadian Journal of University Continuing Education, 26(1), 53-77.

Goldstein, L. S. (2005). Becoming a teacher as a hero's journey: Using metaphor in preservice teacher education. Teacher Education Quarterly, 32, 7-24.

Guerrero, M., \& Villamil, O. S. (2001). Metaphor Analysis in Second/Foreign Language Instruction: A Sociocultural Perspective. Retrieved November, 1, 2015 from http://files.eric.ed.gov/fulltext/ED461990.pdf.

Howell, D. (2014). Fundamental statistics for the behavioral sciences. Cengage Learning.

Johnson, K. E. (1994). The emerging beliefs and instructional practices of preservice English as a second language teachers. Teaching and Teacher Education, 10 (4), 439-52.

Lakoff, G., \& Johnson, M. (1980a). Conceptual metaphor in everyday language. The Journal of Philosophy, 453-486.

Lakoff, G., \& Johnson, M. (1980b). Metaphors We Live By. Chicago, IL: University of Chicago Press.

Lave, J. 1988. Cognition in practice. New York: Cambridge University Press.

Leavy, A. M., McSorley, F. A., \& Boté, L. A. (2007). An examination of what metaphor construction reveals about the evolution of preservice teachers' beliefs about teaching and learning. Teaching and Teacher Education, 23(7), 1217-1233.

Lee, I. (2010). Writing teacher education and teacher learning: Testimonies of four EFL teachers. Journal of Second Language Writing, 19(3), 143-157.

McEwan, A. E. (2007). Do metaphors matter in higher education? Journal of College and Character, 8(2).

Nikitina, L., \& Furuoka, F. (2008). "A Language Teacher is Like...": Examining Malaysian Students' Perceptions of Language Teachers through Metaphor Analysis. Online Submission, 5(2), 192-205.

Nunan, D. (1998). Teaching grammar in context. ELT journal, 52(2), 101-109.

Oxford, R. L., Tomlinson, S., Barcelos, A., Harrington, C., Lavine, R. Z., Saleh, A., \& Longhini, A. (1998). Clashing metaphors about classroom teachers: Toward a systematic typology for the language teaching field. System, 26(1), 3-50.

Perry, C., \& Cooper, M. (2001). Metaphors are good mirrors: Reflecting on change for teacher educators. Reflective Practice, 2(1), 41-52.

Pinnegar, S., Mangelson, J., Reed, M., \& Groves, S. (2011). Exploring pre-service teachers' metaphor plotlines. Teaching and Teacher Education, 27(3), 639-647.

Saban, A., B.N. Kocbeker, and A. Saban. 2007. Prospective teachers' conceptions of teaching and learning revealed through metaphor analysis. Learning and Instruction, 17(2), 123-39.

Seferoğlu, G., Korkmazgil, S., \& Ölçü, Z. (2009). Gaining insights into teachers' ways of thinking via metaphors. Educational Studies, 35(3), 323-335.

Stofflett, R. (1996). Metaphor development by secondary teachers enrolled in graduate teacher education. Teaching and Teacher Education, 12(6), 577-589.

Thomas, L., \& Beauchamp, C. (2011). Understanding new teachers' professional identities through metaphor. Teaching and Teacher Education, 27(4), 762-769. 
Thornbury, S. (1991). Metaphors we work by: EFL and its metaphors. ELT Journal, 45(3), 193-200

Villamil, O. S., \& Guerrero, M. C. (2005). Constructing theoretical notions of L2 writing through metaphor conceptualization. In Applied Linguistics and Language Teacher Education (pp. 79-90). Springer US.

Weber, R. P. (1990). Basic content analysis (No. 49). Sage.

Weber, S., \& Mitchell, C. (1996). Drawing ourselves into teaching: Studying the images that shape and distort teacher education. Teaching and Teacher Education, 12(3), 303-313.

Yesilbursa, A. (2012). Using metaphor to explore the professional role identities of higher education English language instructors. Procedia-Social and Behavioral Sciences, 46, 468-472.

Yigitoglu, N., \& Belcher, D. (2014). Exploring L2 writing teacher cognition from an experiential perspective: The role learning to write may play in professional beliefs and practices. System, 47, 116-124. 